\title{
Domestic Violence, Institutional Response and challenges in Addressing Domestic Violence in Albania
}

\author{
Aurela Bozo \\ (PhD Candidate in Sociology. Faculty of Social Sciences, Tirana University), \\ Sociologist/Lawyer, Center for Legal Civic Initiatives \\ Email:aurboz@yahoo.com
}

\section{Doi:10.5901/mjss.2015.v6n1s1p450}

\begin{abstract}
Domestic violence in Albania continuous to be a concerned issue. Although new civil and criminal legislation legislation is approved aiming to make the law in compliance with international standards, the facts and figures have an increasing trend. The non effectiveness in the enforcement of the civil and criminal legislation is analysed in relation to the responsibilities of the responsible authorities and the role of community in Albania in addressing this problem. The aim of this article is to identify the gaps in the fulfilment of responsibilities by actors and mentality which effects the reaction of community and to recommend interventions aiming to improve the situation of women and children as the members of the family who are mostly faced with violence in family relations. The positive steps undertaken in addressing domestic violence are also analysed in this article. Having the possibility to work and support the victims of domestic violence, the author has used her everyday experience giving the problems through real stories.
\end{abstract}

Keywords: public lawsuit, protection order, effectiveness, criminal legislation, CEDAW.

\section{Introduction}

Different sources of data, official data of state institutions and data from the civil society sector in Albania present the violence in family relations as a concern issue.

Based in the data from General Police Department in Albania, there are identified 2181 cases of domestic violence in 2011; 2526 cases of domestic violence in 2012 and the number of identified cases of domestic violence in 2013 is 3020 cases. The prevalence of domestic violence in Albania has also been one of the main concerns of CEDAW Committee expressed in it's concluding observations for Albania in it's 46th session on July 12-30, 2010.

Women are members of the family who are the most violated within the families. According to a National population-based survey, of 2013, "Domestic Violence in Albania", it has resulted that $53.7 \%$ of women between 18 and 55 years of age were "currently" experiencing domestic violence (all types) \{within the 12 months prior to the interview\}; $52.8 \%$ were "currently" experiencing psychological violence; $14.7 \%$ were "currently" experiencing physical violence; $5 \%$ were "currently" experiencing sexual violence and $16.2 \%$ were "currently experiencing both physical and sexual violence. (INSTAT 2013)

These data in national level shows clearly that domestic violence continuous to be a concern issue for women in Albania, stressing that domestic violence is a gender based violence.

Data from other sources also stress the fact that women continues to be the member of family mostly faced with domestic violence.

This finding resulted also from a monitoring report of the Center for Legal Civic Initiatives, a non profitable organization in Albania which aims to increase the access of violated women and girls in the justice system.

$\mathrm{CLCl}$ monitored urgent protection orders and protection orders from January 2011 to May 2012, at the district court of Tirana. Thus in $89 \%$ of the cases from the monitored decisions in 2011 at the District Court of Tirana, the claims of urgent protection orders and/or protection orders are presented by women. Remaining further in Tirana, in $92 \%$ of the cases during the monitored period of time from January to May 31, 2012, the claims of urgent protection orders and/or protection orders are presented by women. (Mandro, Bozo \& Anastasi, 2013)

This is the situation of domestic violence in Albania, an increased number of the identification of cases of domestic violence, an increased number of denunciations and an increased number of women as the most violated person in the family relations who ask protection from violence in family relations from the responsible authorities.

The Legal framework and it's addings and amendments are in change aiming to be in compliance with international 
standards.

The Constitution of Republic of Albania, the highest legal act has envisaged that everyone is equal before the law.

The Albanian State has ratified many international conventions focused on human rights. UN Covenant on Civil and Political Rights, UN International Covenant on Economic, Social and Cultural Rights, European Convention for the Protection of Human Rights and Fundamental Freedoms are ratified by Albanian state.

With the law no.1769, dated 9.11.1993, The Albanian State has ratified Convention on the Elimination of All Forms of Discrimination Against Women, CEDAW Convention.

With the law no.104/2012, "On ratification of the Convention of the Council of Europe 'On prevention and combating violence against women and domestic violence"', the Albanian state has ratified an international convention which specifically address domestic violence and violence against women. Through ratification of this Convention, the Albanian state has given the message that it is ready to take responsibilities and to undertake measures to fulfil the obligations stemming from this Convention.

Regarding the national legislation, Albania has a specific administrative-civil law, no.9669, dated 18.12.2006, "On measures against violence in family relations", changed which provides for the members of the family faced with domestic violence two remedies, urgent protection order and protection order. The approval of this law was in compliance with the recommendations of CEDAW Committee for Albania in 2003, to have a specific law addressing domestic violence. With a Decision of the Council of Ministers no.334, dated 17.2.2011, "The Set Up of the Mechanism of Coordination and Referral of cases of domestic violence and it's way of proceeding", it is established a mechanism in local level which is made of the Steering Committee, inter disciplinary team and local coordinator for referral of cases of domestic violence and managing cases of $d v$ in a coordinated way in local level. This coordinated approach in local level is based on the needs of victims, as shelter, counselling, legal aid, employment, etc.

According to CEDAW Recommendations since 2003 and repeated in 2010, is not proper response to address domestic violence through general articles of the Criminal Code as it was before in Albania. The specific articles in the Criminal Code of Albania were recommended from CEDAW Committee in 2003 and 2010.

According to Law no.23/2012, "On some additions and amendments on Law no.7895, dated 27.01.1995 in the Criminal Code of the Republic of Albania", as amended, the domestic violence is sanctioned as a special criminal offence in Article 130/a. Article 130/a of the Criminal Code "Domestic violence": 1)beating, as well as any other act of violence against a person who is a spouse, former spouse, cohabitant, or ex cohabitant, close sex or close marriage relations to the offender, by violating the physical, psychological and economic integrity, is punished up to two years imprisonment, as well as 2) a serious threat of death or grave injury against a person who is spouse, former spouse, cohabitant, or ex cohabitant, close sex or close marriage relations to the offender, by violating the psychological integrity, is punished up to three years imprisonment, and 3) wilful injury done to the person who is the spouse, former spouse, cohabitant or ex cohabitant, or close sex or close marriage relations to the offender, with the violation of the physic integrity and causing temporary working disability for more than 9 days, is punished with up to five years imprisonment, 4) the same criminal offenses committed repeatedly or in the presence of the children are punished with up to from 1 to 5 years imprisonment.

The changes of the Albanian Criminal Code in 2012 and 2013 consist in prosecution of stalking (article 121/a); the prosecution of physical and psychological maltreatment of minors by their family members (article 124); there are added as aggravating circumstances cases a)when the offence is committed in violation of protection orders; $b$ ) when the offence is committed in abuse of family and cohabitation relationships; c)when the offence is committed based on motives related to gender, gender identity, etc; the prosecution of sexual or homosexual intercourse with extended family members (article 106), etc.;

There are undertaken steps in addressing domestic violence through policies in central and local level. A national Strategy on Gender Equality and against Gender based and Domestic Violence for 2011-2015 is developed, approved and in the process of implementation. There are developing local strategies and action plans in the municipality level too. These policies have included priorities in addressing violence against women and especially domestic violence. Different agencies of UN and other donors in Albania are working strongly on developing these policies and action plans in response to the needs of the victims of gender based violence. (It is used the term victim, in compliance with the civil law no.9669, dated 18.12.2006, "On measures against violence in family relations", changed)

There are developed policies in the gender perspective in Burrel municipality, action plan in Fier municipality, there are in the process of development the policies in the gender perspective in Durres municipality, Korca municipality, etc with the support of UNDP. They have included priorities in addressing domestic violence in local level.

The budgeting of this policies need to be improved aiming to make these policies effective tools. Other challenges are related to the capacities of the responsible in local level, the level of coordination of efforts between all actors, the fact that some of the actors are reluctant to cooperate, etc. 
Background of the research

Although domestic violence is identified as a concern issue for the Albanian society after 1990, it has also existed in the past, prior 1990. Human Rights were an important issue of discussion after 1990 and they raised the issue that domestic violence is a violation of women's human rights and human rights of other members of the family faced with violence in family relations. There are prepared many papers, studies and reports on domestic violence which have analysed the causes of this phenomena, it's content and the aim of this paper is to analyse effectivenes in the implementation of legislation, how the victims enjoy their right envisaged in the law to be protected from violence in the family.

\subsection{Method}

Mixed methods of research

The author decided to use mixed methods research because of the advantage of mixed methods. It is argued that mixed research methods have several advantages. Mixed methods provide guidance for others in connection with what researchers are intended to do or have done (Creswell 2003 ).

To prepare this article there are used secondary sources of data, thus data produced before by the others (Matthews. B \& Ross 2010) and data provided by the author through interviews of the representatives of the responsible actors and victims of domestic violence. There are interviewed 5 local coordinators and 40 victims of domestic violence supported with free legal aid from a non profitable organization in Tirana, Center for Legal Civic Initiatives. use them.

Some data are produced from the General Police Department and the author is authorised from this Department to

The official documents published from state institutions, political parties, etc or archived near them make an important source, information which can not be replaced. (Dervishi 2013)

These official data, the official statistics as an important source of research have these strong points: at first, they have provided the possibility of using the big champion; The official documents make a very important source of information. Most of the information secured through these documents, is not possible to be gathered with other methods of sociological research. (Dervishi 2013) secondly, these data are produced in national level, thus they give a whole presentation of prevalence of domestic violence in national level;

Thirdly, since data are produced every year they create the possibility to use them in comparable way from year to year. At fourth, these official data are produced recently, so they create a clear presentation of the existing situation;

At fifth, they reflect the social changes. These data give the possibility to analyse trends related to this social phenomena of domestic violence. So they create the possibility of combination of secondary data produced before, to produce new data.

\section{Materials}

The practice of supporting victims of domestic violence with free legal aid is used in this paper. Quantitative data from the General Police Department are used in this article. Data from INSTAT on prevalence of domestic violence and it's addressing are also used in this article. Albania.

Quantitative information is gathered through filling questionnaires by the local coordinator in some municipalities of

Real stories of the victims of domestic violence focusing in the effectivenes of the available remedies, legislation and policies are also used to conclude findings, reccommendations and to have a discussion on the issue.

\section{Analysis Result}

Effectiveness of the implementation of the legislation which address violence in family relations.

\subsection{The civil law no.9669, dated 18.12.2006, "On measures against violence in family relations:, changed.}

Two remedies envisaged in this law, urgent protection orders and protection orders are issued from the district judicial court aiming to prevent and protect victims of domestic violence. (Article 3 of the law no.9669, dated 18.12.2006, "On measures against violence in family relations", changed). 
These remedies are used to protect the victims not only in cases of physical violence but also in cases in which violence has been only psychological violence. One of the cases of a victim of psychological violence supported with free legal aid has been the case of $\mathrm{I}$.

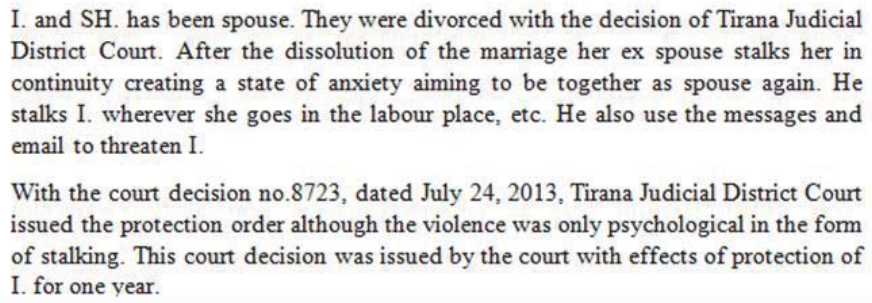

Protection order which is a remedy issued by the court to protect victims from violence in family relations can include one or more protection measures, which reflect the social development in Albania or in some cases they aim to be initiators of these changes reflecting in a clear way the strong connection between them. It is quite clear that in the first years of the implementation of the civil law against domestic violence, the court has envisaged often emergency measures as: the obligation of the violator not to contact the victim, not to threaten her, to stay in a distance from her, not to approach to labour place, not to approach to the origin family, etc. (Article 10 of the law no.9669, dated 18.12.2006, "On measures against violence in family relations", changed)

The diversity of included measures in protection orders from the district courts is evident during the recent years including measures which are connected with restrictions or prohibitions of the contact of the violator with children, with spouse or ex spouse, prohibition of the violator to enter in the temporary or permanent dwelling place of the victim, regardless of his rights of property or possessing on the dwelling place, temporary transferring of the custody right to the victim, temporary removal of the parental responsibility from the violator. These measures have had as aim not only prevention and protection from domestic violence but also eradication of stereotypes as "spouse, ex spouse, children, home are property of husband", etc.

But, regardless of the aim of the law, it seems that eradication of stereotypes continues to be a challenge for legislation, policies, responsible actors, family and our society.

Which are some of the problems identified?

\subsection{The violation of urgent protection orders/protection orders}

The number of protection orders issued by the court are a good example of the implementation of the law no.9669, dated 18.12.2006, "On measures against violence in family relations", changed. But, the violation of protection orders is a clear examples of the fact that these stereotypes continues to be strong and the coordination efforts of responsible authorities need to be strengthened.

Thus, referring to the official data of the General Police Department, regarding the violation of urgent protection orders and/or protection orders it results that there are violated protection orders/urgent protection orders in 86 cases for the year 2011; 119 cases for the year 2012 and 138 cases for the year 2013. These data reflect also the need to strengthen the work of the responsible authorities to implement protection orders.

It has resulted that the role of the Bailiff Office, the police and the Offices of Social Services near municipalities and communes need to be strengthened, as the main responsible actors in the implementation of protection orders based in the law no.9669, dated 18.12.2006, "On measures against violence in family relations". (Article 23, "The enforcement of the court decision", of the law no.9669, dated 18.12.2006, "On measures against violence in family relations", changed.)

A better coordination of the work of these actors would make possible an integrated approach for the victims of domestic violence. The role of the Offices of Social Services in municipalities or communes, regarding the implementation of protection orders is vague. It is necessary to have a strengthened coordination between police and bailiff service in the cases of implementation of protection orders. It results that the responsible authorities in some cases continues to think that domestic violence is a private issue and not a public issue.

\subsection{The ceased decisions on issuing urgent protection order/protection order}

The lack of coordination between responsible actors is reflected also in the ceased decisions of different district courts, 
on issuing urgent protection orders or protection orders.

According to the monitoring report of $\mathrm{CLCl}$, "in year 2011, from 182 decisions on issuing urgent protection orders or protection orders issued by the District Court of Tirana, in 111 cases or in $61 \%$ of the cases the court has decided to cease the case. ...From 111 ceased decisions, in 101 cases or in $91 \%$ of the cases, the claim of issuing urgent protection orders/protection orders were presented by females. In 2012, at the District Court of Tirana, from 239 decisions on issuing urgent protection orders/protection orders issued by the District Court of Tirana, in 154 cases or in $64 \%$ of the cases, the court has decided to cease the case....From 154 decisions being ceased, in 143 of them or in $92 \%$ of the cases the claim of urgent protection orders/protection orders were presented by females." (Mandro, Bozo \& Anastasi 2013)

Usually there are two causes of the ceased decisions on issuing protection orders: trial dismissal for nonapperance of the plaintiff and trial dismissal upon request of the plaintiff. These two causes are envisaged in the Albanian procedural legislation. It seems that it is up to the victim of domestic violence not to be present in the court session or to present a request of withdrawing from the process. But it is not a reality. It is not victim who have decided her case to be ceased. Based in ten years of experience as a lawyer, supporting the victims of domestic violence the victims might have taken this decision not to pursue case trial for fear of another even more extreme act of violence exercised by the violator.

This fear is linked with the fact that victim are felt uncertain that due protection would be offered for them by the responsible authorities, under the frame of the implementation of protection orders. This situation ask a better response of responsible autorities in addressing domestic violence in Albania.

\subsection{Responsible Actors are hesitating to use the right of submission of "Public lawsuit" remedy.}

From different monitoring reports and data, it has resulted that the responsible authorities have not used the right to submitt a request for protection orders as a public lawsuit. Police and prosecutor's office are the main actors which have this legal right and not exercise it. The public lawsuit means that the suitor will be police for example or prosecutor's office and the next party will be violator. This right is very important because, according to the law no.9669, dated 18.12.2006, "On measures against violence in family relations", in cases when the lawsuit is submitted from the police or prosecutor's office the court is obliged to continue the trial even if the victim of domestic violence is withdrawn from the proces. (Article 16, "the judgement on issuing protection order", of the law no.9669, dated 18.12.2006, "On measures against violence in family relations", changed.)

This would make possible that the perpetrator will face the law even in the cases when the victims are feared, threatened to submitt a request for protection order or are withdrawn from the process even in cases of submission a request for protection order.

Based in the interviwes with 40 victims of domestic violence, it has resulted that they have no information regarding this right of the police and prosecutor's office to submitt the public lawsuit. They have shared the information that in their cases, the police has supported the victims of domestic violence in preparation of a lawsuit with the suitor the victim of domestic violence and the defendant the perpetrator.

Why there are no cases of public lawsuits? Why. although the police officers and prosecutors are well trained during recent years on the implementation of the legislation which adress domestic violence, they are reluctunt to use this remedy?

I think that the main reason is that police officers, prosecutors are part of the society, they reflect the mentality of society and they continue to think that domestic violence is a private issue and not a public issue without understanding that the right that violates domestic violence are not only the rights of the memebers of the family but also the public rights and welfare.

CEDAW Committee in it's concluding observations for Albania in it's 46th session on July 12-30, 2010 recommended that the Albanian state to secure that the public civil servants, especially the persons responsible for the enforcement of the legislation, the judges, health service representatives, social workers to be fully sensitised on all forms of violence against women. The cooperation with nongovernmental organizations was recommended strongly.

\subsection{The passive role of community is the reflection of low level of belief that the system functions.}

The law no.9669, dated 18.12.2006, "On measures against violence in family relations" has envisaged that community can play an active role in addressing domestic violence through reporting and denunciations. Although the civil law has envisaged an active role, the community continue to stay passive in cases of violence in family relations, continuing to consider these cases as private issues, which belongs only to members of the family. From my practice as lawyer 
working with victims of domestic violence, it is noted that the cases of domestic violence are prosecuted or it is used the civil law on the prevention of domestic violence with civil remedies based mainly in the denunciation of the victim or in a restricted number of cases in the denunciations of the members of the family of the victims.

There are two perspectives: the first one, if the law does not reflect the level of emancipation of the society, but it has high expectation from citizens then this fact will be demonstrated in the practice, making that this legal prognosis to be not enforced, to be simply an article without implementation. Non implementation of this legal prognosis expresses clearly that regardless of the steps undertaken by the Albanian society in it's emancipation, it continues to consider the family as a closed unit, which problems has not to be made public. Thus, domestic violence continue to be considered as private issue by the community in Albania. On the other side, this reflect the fact that the law can contribute in changing the mentality, showing that when the forces of circumstances create inequality then the forces of legislation have to change it, as Ruso thought.

How to make the community more active? I think that except the need to increase the awareness of the community using family, school, campaigns, education, media it is necessary to increase the belief in the functioning of the system. The response of the authorities for concrete cases of domestic violence contribute in increasing the belief of the community in the system and motivate the public to be active.

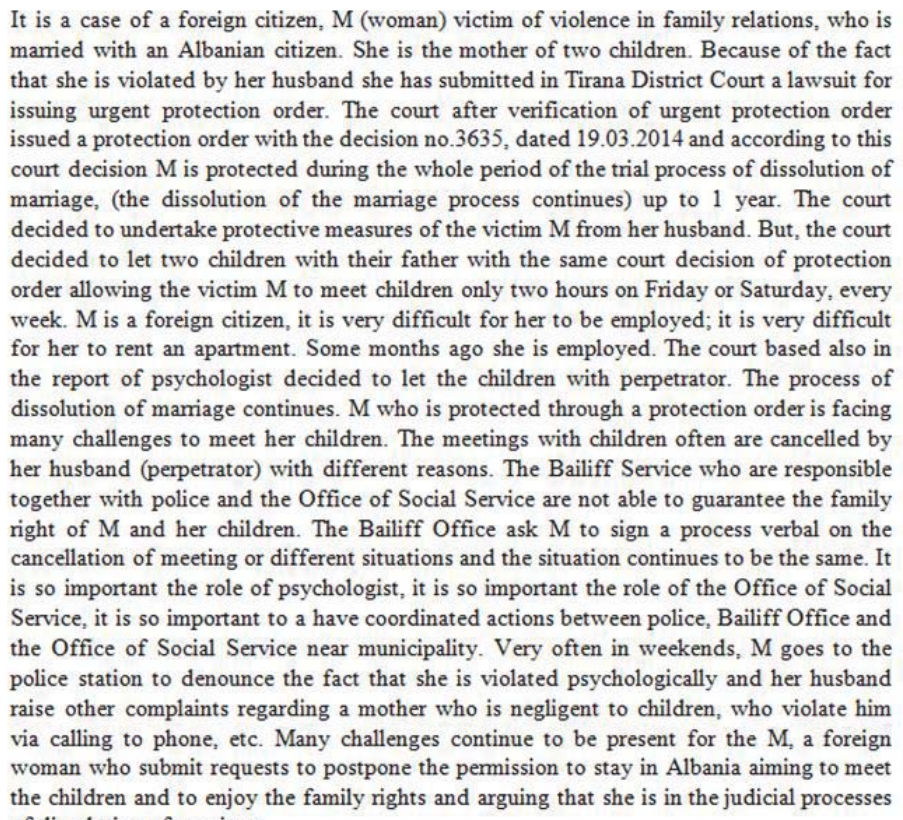

\section{Women, foreign citizens married with Albanian citizens, women from different minorities faced with domestic violence reflect clearly how necessary is that the responsible authorities to react in a coordinated way.}

The case of $\mathrm{M}$, make present how effective have to be the measures of the Albanian State to fulfil the obligations stemming from the Convention of the Council of Europe 'On prevention and combating violence against women and domestic violence"'.

According to this Convention, the State Parties have to undertake the necessary legislative measures or other measures to guarantee that:

- the violence incidents are considered in the decision of parental responsibility and the right of visiting children;

- during exercising the right of visit of children not to put in risk the security of the victim and of children.

- the visits of children have to be supervised by a psychologist or social worker;

- the state parties to secure that in the case of violation of protection orders, the authors of violation to be exercised to criminal sanctions or other effective legal sanctions. Although it is foreseen in the article 321 of the Albanian Criminal Code that the violation of protection order is a criminal act, the cooperation between police, prosecutor office and the court is not effective in some cases.

This case raise the issue of the connection between violence and discrimination of women from minorities. The 
cases of women with disabilities, women from Roma community, etc are very difficult to be addressed properly because they need more specific services and coordination of efforts.

According to the data from General Police Department it has resulted that, women from minorities are also faced with domestic violence. Referring to these data there are 23 cases or $1 \%$ of the total number of cases, citizens from different minorities for the year 2011, there are 16 cases or $0,6 \%$ of cases for the year 2012 and there are 38 cases or $1,2 \%$ of the total cases for the year 2013. This is an increasing trend in facing of women from minorities with violence in family relations, which asks for attention and measures.

\subsection{The effectiveness of implementation of recent changes in the Albanian Criminal Code}

Recent changes in 2012 and 2013 in the Albanian Criminal Code has brought increasing number of criminal cases related to domestic violence.

During 2011 there are referred in the Prosecutor's office 495 criminal cases happened in the family relations. During 2012, there are referred in the Prosecutor's office 867 criminal cases happened in family relations. The changes in the Criminal Code in 2012 which have foreseen domestic violence as a criminal act (the article 130/a) have brought increasing of number referred to Prosecutor's office for criminal prosecution. During 2013 there are referred in the Prosecutor's office 1212 criminal cases happened in family relations.

Center for Legal Civic Initiatives monitored the court decisions of District Court of Tirana, in the implementation of the article 130/a "Domestic violence" of the Criminal Code as amended for the period April 31.2012-December 31, 2012. According to the monitoring report, 26 cases were presented before the court, but in 17 of these cases the court has decided to cease the case.....From the analyses of the decisions it results that the court has decided the cessation for the 17 cases according to Law no.107/2012 "On Amnesty"1. (Mandro, Bozo \& Anastasi, 2013)

The number of cases deceased is high reflecting the non effectiveness of the implementation of the article 130/a not because of the legislation in itself but because of the fact that the responsible authorities have to consider that these criminal cases are of high risk not only for the members of the family but for the society and have not to be amnestied.

There are challenges for the victims of domestic violence when they are not informed that the perpetrator is free from prison and they are in a real risk.

According to Albanian legislation, a victim of domestic violence can use the civil and criminal legislation to be protected from domestic violence ${ }^{2}$. One of this cases supported with free legal aid from the lawyers of $\mathrm{CLCl}$ was the case $\mathrm{H}$. and her daughter $\mathrm{J}$..

- $\quad H$. has denounced her husband to the police station for the violence exercised from him on $H$. and her daughter. The police and prosecutor's office started the criminal prosecution and Tirana Judicial District Court found him guilty and sanctioned with 6 months in prison. H., the wife of perpetrator was informed by her neighbours that her husband has seen him around the home of $\mathrm{H}$. This fact made $\mathrm{H}$. and her daughter to be felt frightened. The perpetrator have sent a message to the victim saying that $\mathrm{H}$. and their daughter will pay with their life the denunciation they have made to the police. In these conditions they submitted to Tirana Judicial District Court a request on issuing urgent protection order. Tirana Judicial District Court with the Act no.16149, dated July 25, 2013 decided to issue urgent protection order for the victim and her daughter. This case shows how important is for the Albanian state to fulfil the obligation stemming from the Convention of the Council of Europe 'On prevention and combating violence against women and domestic violence"', to secure that the victims are informed, at least in cases when the victim and her family might be in risk, when the author of criminal act is free from the prison permanently or temporary.

\section{Discussion and Recommendations}

- Domestic violence is a concern issue in the Albanian society and the data shows that the number of denunciations is increasing. It is recommended that the awareness of the society on all forms of violence in family relations to be strengthened.

- Although a progress is made, the level of coordination between responsible actors on addressing domestic violence is low. It is recommended the remedies in cases of the violation of legal responsibilities by the responsible authorities to be used aiming to make them more responsible and to offer an integrated approach

\footnotetext{
${ }^{2}$ Article 24, "Criminal prosecution", of the law no.9669, dated 18.12.2006, "On measures against violence in family relations", changed. 
for the victims of domestic violence.

- Using of the right of public lawsuit from the police or prosecutor's office is vague. It is recommended that the law no.9669, dated 18.12.2006, "On measures against violence in family relations" to change the submission of the public lawsuit from a right of the police and prosecutor's office to an legal obligation. It is necessary in cases of the victims of domestic violence who are in fear that if they denounce domestic violence the perpetrator will be more violent upon the victims. It would make possible that the perpetrator to be faced with the power of the enforcement of legislation.

- The number of the cases of the enforcement of the article 130/a of the Criminal Code "Domestic violence" is limited. It is recommended a better coordination between police, prosecutor's office, etc aiming to offer protection of domestic violence.

- There is a lack of effective policies, services and measures for women who belongs different minorities. It is recommended undertaken of effective measures to prevent and protect women from multiply violence and discrimination.

- there is lack of information of the victims of domestic violence in cases when the perpetrator are free from the prison and this put the victims in a real risk. It is recommended the state to secure that the victims are informed, at least in cases when the victim and her family might be in risk, when the author of criminal act is free from the prison permanently or temporary.

- The stereotypes effects the work of responsible authorities and communities as a whole. It is recommended the state to use all yaws as trainings, education, etc to eradicate these stereotypes.

\section{References}

Legal acts

The Constitution of Republic of Albania

UN Covenant on Civil and Political Rights, ratified on October 4, 1991;

UN International Covenant on Economic, Social and Cultural Rights, ratified on October 4, 1991;

European Convention for the Protection of Human Rights and Fundamental Freedoms, ratified on February 10, 1996;

Convention on the Elimination of All forms of Discrimination Against Women, ratified on November 9, 1993;

Convention of the Council of Europe 'On prevention and combating violence against women and domestic violence"', ratified in 2012;

The law no.9669, dated 18.12.2006, "On measures against violence in family relations", changed;

The Albanian Criminal Code, changed in 2012 and 2013, with Law no.23/2012, "On some addings and changes in the law no.7895, dated 27.01.1995, "The Criminal Code of Republic of Albania", changed and with law no.144/2013

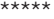

INSTAT, (2013) Domestic Violence in Albania, National population-based survey, p.33, Tirana.

Mandro, A \& Bozo, A \& Anastasi, A (2013) Report on Knowledge and implementation of the gender equality standards in court decisions, January 2011-June 1, 2012, p.51.Tirana, Daji 2000.

Matthews, B \& Ross. L., (2010) "Methods of Research", p.285, Tirana, CDE.

Dervishi.Z, (2013), "Sociology", p.28, Tirana SHBLSH e re.

Mandro, A \& Bozo, A \& Anastasi, A (2013) Report on Knowledge and implementation of the gender equality standards in court decisions, January 2011-June 1, 2012, p.53, Tirana, Dajit 2000.

Mandro,A \& Bozo, A \& Anastasi, A (2013) Report on Knowledge and implementation of the gender equality standards in court decisions, January 2011-June 1, 2012, p.53.

It is consulted the practice of the Center for Legal Civic Initiatives, the decision of Tirana Judicial District Court no.8723, dated 24.07.2013, the Act no.16149, dated July 25, 2013 of Tirana Judicial District Court and the decision no.3635, dated 19.03.2014 of Tirana Judicial District Court. 